\title{
THE SYMBOLIC SPHERE AND SOCIAL REPRESENTATIONS OF SERRA DA TIRIRICA STATE PARK, RIO DE JANEIRO, BRAZIL
}

\section{A esfera simbólica e representações sociais do Parque Estadual da Serra da Tiririca, Rio de Janeiro, Brasil}

\author{
Douglas de Souza Pimentel \\ Grupo de Estudos Interdisciplinares do Ambiente (GEIA) \\ Universidade do Estado do Rio de Janeiro \\ Universidade Federal Fluminense \\ Rio de Janeiro/RJ - Brasil \\ douglasgeia@gmail.com \\ Teresa Cristina Magro \\ Professor Doutor do Departamento de Ciências Florestais, Escola Superior de Agricultura Luiz de Queiroz - USP \\ São Paulo/SP - Brasil \\ ojs-tecmagro+tecmagro@esalq.usp.br
}

Artigo recebido para publicação em 02/02/2011 e aceito para publicação em 18/07/2011.

ABSTRACT: Serra da Tiririca State Park (Parque Estadual da Serra da Tiririca-PESET) is located in an area of rich environmental history between the cities of Niterói and Maricá in Rio de Janeiro State, Brazil. Established through grassroots lobbying and popular mobilization, it nevertheless hosted some mistakes that catalyzed social problems, which should have been otherwise dealt with during its creation process. We believe that social representations allow us to learn about the symbolic sphere of the social insertion of protected areas. On the one hand, the protected area is seen as a "paper park" and as a stage where conflicts related to real-estate speculation, land ownership and the political situation take place. Its positive image, on the other hand, refers to the political mobilization for its creation and to the community's vigilance. As a conclusion, the social representations must be understood so that its positive aspects may be highlighted, contribute to its regional incorporation and aid in the Park's management.

Keywords: State Park. Symbolic image. Management. Social representations.

RESUMO: $\quad$ O Parque Estadual da Serra da Tiririca (PESET) está localizado em uma região de rica história ambiental entre as cidades de Niterói e Marica no estado do Rio de Janeiro, Brasil. Apesar de ter sido criado à partir de forte mobilização popular alguns passos dentro do processo catalisaram problemas sociais que deveriam ter sido gerenciados com a criação do Parque. Acreditamos que representações sociais permitem conhecer a esfera simbólica da inserção social das áreas protegidas. Por um lado a área protegida é vista como um parque de papel e como um palco de conflitos relacionados à especulação imobiliária, situação fundiária e política. A sua imagem positiva, por outro lado, refere-se à mobilização política pela sua criação e a vigilância da sociedade. Como conclusão, as representações sociais devem ser compreendidas para que seus aspectos positivos sejam ressaltados, contribuam para a sua inserção regional e auxiliem a gestão do Parque.

Palavras-chave: Parque Estadual da Serra da Tiririca. Imagem. Gestão. Representações sociais. 


\section{INTRODUCTION}

Managing parks involves different social and biological scales that end up influencing how society perceives the protected area and its administration. Ecology parks and other strict, full-protection areas represent an effective conservation tool when properly managed (Terborgh, 2000, 2007). However, from the social point of view parks still deal with liabilities related to management decisions and to conflicts with surrounding communities and visitors. These views must be integrated so that better efficiency and effectiveness in conservation may be attained, nevertheless, it is a controversial and complex process that encompasses territorial implantation, legal restrictions and public perception of symbolic and administrative aspects of the park.

Tiririca Mountains State Park comprises a long crystalline massif almost perpendicular to the seacoast. The mountain range separates the municipalities of Maricá and Niterói in the state of Rio de Janeiro (Brazil). Despite its biological importance - it harbors animal and plants either endemic or representative of the Atlantic rainforest - the Park represents a process of social concept from a "paper park", defined on maps by government under environmentalists' pressure to a popular defense and some problems with indigenous communities. All this history shows relevant characteristics, including the pressure of real-estate speculation, which advanced rapaciously over prime areas in the region and particularly around the mountain range, and a popular reaction through technical (lawsuits, Park's perimeter mapping) and political actions that demanded the Park's establishment.

Stemming from that grassroots mobilization, studies primarily by the NGO Movimento Cidadania Ecológica-MCE (Ecological Citizenship Movement) and other entities presented the technical and legal grounds for the law that created PESET, sanctioned in 1991. However, that law did not delineate the Park's physical boundaries, as it was believed they could be established with the participation of representatives of the civilian society and state agencies. In March 1993 a commission was charged with the task of defining procedures for its definitive demarcation. Later that year a state decree established the provisional boundaries of
PESET. Not until 2006 was a bill proposed in the State Legislative House establishing the definitive perimeter of PESET. However, hurdles had yet to be overcome in the House. It was in this political situation that the park's definitive boundaries were finally sanctioned on September 3, 2007 but, because of the real-estate occupation process in its area, its size was cut down.

This complex process, along with a long history of occupation in the region led to the creation of a social perception of PESET, a set of symbolic meanings which influences its management to date. So, the institutionalization of a park, that involves territorial, administrative, legal and political spheres, also implies the acknowledgment of this symbolic referential (Ropper, 2000; Paasi, 2002), which can be evidenced by social representations that arise from the cognitive processing of information and from individual and community experiences. Those are not limited to identifying beliefs and attitudes, but also encompass their structuring into interacting groups that evolve with time and are shared similarly to language (Bauer; Gaskell, 1999). That interactive system does not function as a linear structure of cause and effect, rendering it unpredictable (Bauer; Gaskell, 1999; Castro; Lima, 2001; Peluso, 2003; Gerhardt; Almeida, 2005). Therefore, in order to understand the relation between society and parks, interdisciplinary research is necessary to identify the factors that either hinder or support the efforts of conservation, that can not rely on Ecological knowledge alone (Bauer; Gaskell, 1999; Ormsby; Kaplin, 2005).

\section{OBJECTIVE}

The objective of this study is to describe the social representations that characterize the symbolic sphere of PESET to seek in them the image of the Park and its administration to society.

\section{METHODS}

Data were collected by means of recorded, semi-structured interviews. All interviews, held in 2006 and 2007, were transcribed. Transcripts made up the document corpus for later use in content analysis procedures as proposed by Bardin (1977). Interview- 
ees were chosen according to the following profiles: 1) Environmentalists associated with the creation and defense of PESET; 2) Management (current and former administrators); 3) Park staff; 4) People associated with ecotourism agencies and adventure sports; 5) Politicians; 6), Residents and community representatives; 7) Real-estate agents and 8) Visitors. Altogether, 26 actors were select trough internet sites related to the Park, administrative staff, frequent visitors, and interviewees' indications. The guide questions encompassed the Park's history perception, as well as the description of the Park and its relations with visitors and nearby residents. Positive and negative views about administration, Park's importance to society, reasons to its defense and perceptions about conservations goals achievements also conduct the interviews.

In content analysis, exploratory "float reading" was done through skimming the transcripts for first impressions, thus guiding formulation of indicators to codify the material. In this first round, sense cores or categories were defined, as well as themes named speeches, phrases that fit the sense cores. Sense cores made up 24 categories equally split into three clusters, one representing a positive view of PESET (cluster 3 ), an intermediary view with situations that may develop into negative or positive actions (cluster 2) and a negative view of PESET (cluster 1). Afterwards, the speeches identified in the interviews transcribed texts were related to their categories and accounted for by means of individual spreadsheets for each actor (Bardin, 1977). Since the interviewees were gathered in two groups, one with an "inside-out" point of view (people with current or former administrative roles in PESET) and the other with an "outside-in" point of view (people not employed by the government to Park's administration), separate analyses of the two groups of data were conducted, but both under the same procedures described above for the total of speeches. Actors' names have been changed.

A reader should be able to replicate your methods, and I could not do so based on this description.

\section{RESULTS}

Percentages of speeches per actor were established in relation to each cluster or supergroup. The list also included percentages of speeches classified into categories in relation to total number of speeches $(1,411$ speeches $)$ and in relation to the categories divided in the three clusters. Categories in cluster 3 represented $24 \%$ of total speeches; those of cluster 2 , approximately $16 \%$ and those of cluster 1 , about $60 \%$. Speeches concerned mainly with conflicting relations with the Park (18.6\%), administrative problems $(15.2 \%)$ and real-estate speculation issues (10.1\%), all of which belong to cluster 1 (TABLE 1).

In cluster 3 (TABLE 1) the most often-cited categories were the historical and social relevance of PESET (25.1\%), references to the fact that the Park was society's demand $(15.9 \%)$ and the perception of improvement to infrastructure (13.3\%). In cluster 2 were comments on managerial efficiency $(29.8 \%)$ and the acknowledgement that PESET's management has to deal with a substantial social liability $(17.8 \%)$. In cluster 1 the same categories that stand out in the general account show up: the perception of conflicts $(31.1 \%)$, management problems $(25.4 \%)$ and real-estate speculation (16.8\%).

Actors with administrative roles yielded 593 speeches, of which $28.7 \%$ were classified in cluster $3,20.2 \%$ in cluster 2 and $51.1 \%$ in cluster 1 . Speeches were mostly in the categories of management problems (16.2\%) and conflicts (10.5\%) in cluster 1 , managerial efficiency and demands $(7.3 \%)$ in cluster 2 and PESET's historical and social relevance in cluster 3. The latter categories also stood out in the percentage counts per cluster with, respectively, $31.7 \%, 20.5 \%$, $35.8 \%$ and $24.7 \%$. In cluster 1 , real-estate speculation $(13.2 \%)$ was also in evidence.

Non-administrative actors yielded 818 speeches. $20.7 \%$ were classified in cluster $3,12.8 \%$ in cluster 2 and $66.5 \%$ in cluster 1 . In the general count, highlights are conflicts $(24.6 \%)$, management problems (14.5\%) and real-estate speculation (12.5\%) in cluster 1 . In the counts per category highlights were the social and historical relevance $(25.4 \%)$ and improvements to infrastructure as well as social demand (both with $13 \%$ of references) in cluster 3. Categories that stood out in cluster 2 were administrative demands $(22.9 \%)$, private interests $(19 \%)$ and social liability (19\%). In cluster 1, categories that stand out are the same as those in the general count: conflicts repre- 
senting $36.9 \%$ of references, management problems with $21.9 \%$ and real-estate speculation with $18.8 \%$.

Table 1 - Total number of speeches and their percentages per cluster and in relation to total

\begin{tabular}{|c|c|c|c|c|c|c|c|c|c|c|c|}
\hline $\begin{array}{l}\text { Categories } \\
\text { cluster } 1\end{array}$ & Total & $\begin{array}{c}\% \\
\text { total }\end{array}$ & $\begin{array}{c}\% \\
\text { cat. }\end{array}$ & $\begin{array}{l}\text { Categories } \\
\text { cluster } 2\end{array}$ & Total & $\begin{array}{c}\% \\
\text { total }\end{array}$ & $\begin{array}{c}\% \\
\text { cat }\end{array}$ & $\begin{array}{c}\text { Categories } \\
\text { Cluster } 3\end{array}$ & Total & $\begin{array}{c}\% \\
\text { total }\end{array}$ & $\begin{array}{c}\% \\
\text { cat }\end{array}$ \\
\hline $\begin{array}{c}\text { Park } \\
\text { boundaries }\end{array}$ & 82 & 5.8 & 9.7 & $\begin{array}{l}\text { Pressure for } \\
\text { boundaries }\end{array}$ & 14 & 1.0 & 6.2 & $\begin{array}{l}\text { Social } \\
\text { demand }\end{array}$ & 54 & 3.8 & 15.9 \\
\hline Conflicts & 263 & 18.6 & 31.1 & $\begin{array}{l}\text { No to the } \\
\text { "conflict } \\
\text { park" }\end{array}$ & 5 & 0.4 & 2.2 & Vigilance & 24 & 1.7 & 7.1 \\
\hline $\begin{array}{l}\text { Various } \\
\text { Problems }\end{array}$ & 59 & 4.2 & 7.0 & $\begin{array}{l}\text { Seek for } \\
\text { managerial } \\
\text { efficiency }\end{array}$ & 67 & 4.7 & 29.8 & $\begin{array}{c}\text { Better } \\
\text { infrastructure }\end{array}$ & 45 & 3.2 & 13.3 \\
\hline $\begin{array}{l}\text { Real-estate } \\
\text { speculation }\end{array}$ & 142 & 10.1 & 16.8 & $\begin{array}{l}\text { Demand for } \\
\text { consultative } \\
\text { committee }\end{array}$ & 18 & 1.3 & 8.0 & $\begin{array}{l}\text { Favorable } \\
\text { conditions }\end{array}$ & 41 & 2.9 & 12.1 \\
\hline $\begin{array}{l}\text { Infrastructure } \\
\text { and financing }\end{array}$ & 51 & 3.6 & 6.0 & $\begin{array}{c}\text { Fight against } \\
\text { private } \\
\text { interests }\end{array}$ & 31 & 2.2 & 13.8 & Good relations & 23 & 1.6 & 6.8 \\
\hline $\begin{array}{c}\text { Management } \\
\text { problems }\end{array}$ & 215 & 15.2 & 25.4 & $\begin{array}{l}\text { Observed } \\
\text { sentimental } \\
\text { relations }\end{array}$ & 15 & 1.1 & 6.7 & $\begin{array}{c}\text { Team's } \\
\text { proactiveness }\end{array}$ & 25 & 1.8 & 7.4 \\
\hline "Paper Park" & 12 & 0.9 & 1.4 & $\begin{array}{c}\text { Park's history } \\
\text { and social } \\
\text { liabilities }\end{array}$ & 40 & 2.8 & 17.8 & $\begin{array}{c}\text { Social } \\
\text { relevance }\end{array}$ & 85 & 6.0 & 25.1 \\
\hline $\begin{array}{l}\text { Bio/eco fra- } \\
\text { gilities }\end{array}$ & 23 & 1.6 & 2.7 & $\begin{array}{l}\text { Search for } \\
\text { Ecological } \\
\text { actions }\end{array}$ & 35 & 2.5 & 15.6 & $\begin{array}{l}\text { Bio/eco } \\
\text { relevance }\end{array}$ & 42 & 3.0 & 12.4 \\
\hline total & 847 & 60.0 & 100 & total & 225 & 15.9 & 100 & total & 339 & 24.0 & 100 \\
\hline
\end{tabular}

Note: Clusters group sense nucleus cores or categories expressed by the key idea of the different themes (speeches): Cluster 1 refers to negative perceptions about the PESET, its administration and relationships with visitors and nearby residents; Cluster 2 brings together some ideas that could evolve to positive or negative situations when pointing some actions to be done; Cluster $\mathbf{3}$ gathers positive perceptions.

\section{DISCUSSION}

The interview transcripts revealed a collection of representations that symbolize the way social actors perceive and relate with PESET. Those representations can have a powerful influence on the Park's management as they account for the symbolic sphere of its process of social insertion, because the Park and the administrative proceedings should gain significance to resident people and visitors to overpass the perception 
of it as an alien institution. Pimentel and Magro (2009) describe a series of arguments used to support the conservation of Tiririca Mountains State Park. They transcend its biological importance, as the arguments associated with the Park's relation with society were the most frequent. The parks' management tend to bio and ecological features to describe its importance and then all these symbolic richness is lost.

PESET's institutional history is positive from the outset because "to tell the story of PESET is to tell the story of the community in the Tiririca Mountains" (Renan, representative of small farmers), “...but the park's history...starts with the environmentalist movement..." (Paula, environmentalist) “... demanding for the institutionalization of a space which by then was merely seen as a mountain...it then faces it all differently" (Andreia, Park management agency).

That view represents the history of PESET both before its inception and as a new entity individualized in the physical and conceptual space of the area. The historical register is related to the evolution of occupation in the region by different social groups, which set the vectors of preservation as well as those of degradation of the protected area, but forming the basis for the process of institutionalization of the space into a park.

PESET is one of the few cases in Brazil of a Park created through popular mobilization, a promising start that carried great hopes for the conservation of that fragment of Atlantic rainforest. Thus, the importance of the Park as the region's historical, social and cultural register also denotes conservationist efforts. That image stands as an important attribute of the positive view. Within cluster 3, which represents the group of positive representations, approximately $25 \%$ of the speeches were in this category.

Nevertheless, after more than 18 years from its inception, there probably has been a deterioration of the symbolic sphere related to PESET, a Park demanded by social groups (a rare case in Brazil). Speeches have tended toward a negative view of the Park, evidenced by the $60 \%$ rate of negative references related to cluster 1 (TABLE 1). Speeches in this group mostly fit the category of conflicts $(18.6 \%$ of general references and $31.1 \%$ within cluster 1 ), associated mainly with the problems on managing the Park, as well as with the historical liability of land-tenure disputes that intensified after its inception. Hence, PESET does not succeeds in informing and convincing people about its importance to conservation of the last forest fragments in Niterói and Maricá. That mismatch ends up fomenting:

a history of conflicts..., it is like the fight of the rock against the water; it is the big condominiums wanting more, to invade the Park and the Park has resisted through the organized entities of environmentalists, of researchers, through the unorganized population, through the Fishermen's Association... (Luis, researcher).

In his interview, Luis also mentions the effects of real-estate speculation, an example of the convergence among the social representations of PESET, as this negative view generates a positive perception of popular mobilization to its protection. Another speech reinforces that position: "the largest conflict with the Park, since it was created, centered on real-estate speculation..." (Helio - state management agency). That interaction was one of the catalysts in the population's organization in the political movement that led to the creation of PESET and that acts in its defense. That view is represented by the category vigilance: “... one of the most important political battles for Niterói's true environmentalists..." (Renam).

Furthermore, there is also the perception that the Park's creation was positive for "...not having allowed real-estate speculation to climb the hills". Niterói's geographic arrangement is similar to that of the city of Rio de Janeiro and the pressure of occupation up the hills took place slowly and little was left of the original vegetation cover in that city, except for Tijuca National Park. Thus, the perception of real-estate speculation leads to both positive and negative effects on the symbolic representation of PESET and its management. The positive aspects are associated with the image of resistance and popular mobilization, past and present, as well as with valuing the Park as an instrument to keep speculative interests at bay. The negative aspects refer to the administrative inefficiency of Instituto Estadual do Ambiente 
- INEA (State Environmental Institute), the state's park management agency, to the delay in implanting PESET and to the perception of suspicious relations of Niterói's and Maricá's municipal authorities with real-estate speculators.

Within categories in cluster 1 , inherent to a negative image of the developers, the view that PESET is subject to pressure from real-estate speculation and unplanned urban expansion of adjacent cities was evidenced by $10.1 \%$ of the speeches in the general count. They represented about $17 \%$ of speeches in the cluster (TABLE 1).

The other representation that reinforces a negative image of the Park relates to its precarious implantation at both territorial (late perimeter definition and land ownership problems) and institutional levels (absence of management plan, environmental education politics and activities, poorly established management council). The Park suffers from internal and external administrative problems associated with the state administration's inaction and the lack of continuity and articulation of actions among municipalities, INEA and local manager, besides a perception of corruption in the state's park management agency and in the municipal governments. They all add to the idea of administrative inefficiency. The category of administrative problems accounted for $15.2 \%$ of the speeches in the general count and for $25 \%$ of the references in cluster 1. Other administrative problems were related to lacks in infrastructure, financing and staffing $(3.6 \%$ of speeches in the general count and $6 \%$ within cluster 1 ) and to the lack of implementation of definitive boundaries of PESET (5.8\% and $9.7 \%$, respectively). Thus, from the point of view of its administrative status the Park could be defined as a "paper park", although that term was specifically used in only $1 \%$ of the speeches (TABLE 1 ).

Another iconic image of PESET is that of conflicts. It has been in a restructuring period due to political and administrative changes in the management agency and in the State of Rio de Janeiro's environmental policy, hence the perception of improvements in management and infrastructure expressed by the managerial efficiency and demands category that totaled almost $30 \%$ of speeches in cluster 2 . However, it is general knowledge that the Park carries a social liability (about $18 \%$ of speeches in cluster 2 ) as one of its most urgent problems, directly linked to the relations between the protected area and the people and to what it represents to society, because the social mobilization was not so broadly and the traditional communities were not initially involved as well as the absence of a state administration for a long period. Those three social representations interact and cause the perception that the Park's administration must strive to “...reverse the Park's stigma as a Conflict Park...we need to reverse that mistake, that is, of society thinking that the Park is one of conflict" (Cláudio).

The roots of that problem can be found in the history of the region and in the more recent developments before, during and after the creation of PESET. A series of processes ensued that compromised the very existence of the Park. One of them, as reported, is represented by the land-tenure conflicts, but other conflicts surfaced such as those among the members of the environmentalist movement that fought for the Park.

In its short existence, based on personal observations and the present research, PESET has gone from a positive relation with society, which demanded for its creation, to one that gave it the reputation of a conflict park. Some actors offer a hint as to how that view may have degraded so fast amidst the clashing of good intentions against the reality of the facts.

Paula defines part of that history and in doing so exposes a third important observation (boldface below by the author):

...the Park was created by the environmentalist movement; in this way it is a positive aspect: people mobilized so that the area would be protected, but they forgot to include in that mobilization the people who live in the area... and who became a problem that no one wants to solve, and some want to keep them out of the process of discussing the Park...

The fourth observation is related to the Park's administration, described by Eva (state management agency):

...our action is still very police-oriented because without a clear definition and with $a$ 
mandate to prevent constructions, you have to approach as police, not as educators; we are not doing Park management; we are actually defending the Park's boundaries.

From what has been stated one can notice that the conflicts derive from factors that are well-known to people that deal with the Park: the long time before its boundaries were set $(5.8 \%$ of all references - cluster 1 - Park boundaries); the administrative inefficiency, unable to act so as to educate for conservation; real-estate speculation $(10.1 \%)$; the presence of communities within the Park area prior to the demarcation of its provisional boundaries and which were excluded from the decision-making processes, and other administrative, infrastructure, financing and staffing problems by the Park's management. That picture supplanted the view of positive aspects, such as the great mobilization for its creation, the defense of the area by the local communities and the good relations with local residents (only 1.6\%) and the widespread vigilance on the Park.

Complementarily, the conflict stigma does not occur due to those factors acting independently, but stem from the synergetic interactions among them: the lack of set boundaries left room for real-estate speculation and is a focus of tensions for communities within and around the Park. That lack is the most visible limitation and inefficiency of the State administration in actually assuming conservation management in Rio de Janeiro. There was mention of the fact that INEA stages political disputes and control by political parties, which, coupled with shortage of funds, insufficient trained staff and discontinuity of projects end up trammeling the Park's management, which has to make do with scattered actions by people linked to its local administration or by actors more engaged in its defense.

Other hypotheses may be raised. The Park has several administrative limitations, but is at the same time seen by many as responsible for safeguarding its territory from real-estate speculation. The Park's inception by means of State legislation limited the action of speculation agents as it removed administration of the space from the local sphere, where it was more vulnerable to political and economic pressures; meanwhile, it also regulated some forms of not sustainable use by traditional communities. However, here also lies the large gap in the institutionalization of the space and the big mistake in the process of PESET's creation. The actors associated with the first steps towards its creation, believing in the innovativeness of popular mobilization to such a cause took advantage of that social movement to lobby for the Park, which was gazetted without having its boundaries delineated. Demarcation was left for a second stage comprising public consultations. Agents of real-estate speculation then found a new niche of influence in the clash of local forces, since the legislative bill of 2006, set to define the boundaries, handed the whole process back to the public consultations, where the speculative interests enjoyed significance and attained actual gains, removing unoccupied lots from the area originally proposed in 1993 . Hence, the view of conflict is also connected to an injustice that affects primarily the poorer communities.

Therefore, definition of the boundaries was critical for the Park's de facto existance, as noted in Nélio's account:

The protected area exists in paper only and the State, legally obliged to implement it, otherwise prefers to resist that obligation in court through appeals that only postpone to a much later date the objectives of PESET, since without demarcation there is no management plan; without a plan, there is no park.

Those remarks allow us to anticipate everincreasing pressures in the Park areas facing Maricá, once the slopes facing Niterói are almost completely surrounded by homes and condominiums.

Furthermore, there is a latent social liability related to those questions, because there is a historic of some Park areas being disaffected to beneficiate private land owners and some traditional people that remains inside Park's boundaries, as pointed by Renam:

...many people could not yet believe what the Park category actually meant, that is, strict 
protection, real possibility of land expropriation...There is nothing to celebrate about this approval of new boundaries; if there were ever a way to stop the urban sprawl, that would have been much more easily done with the limits of 1993; now it is in the hands of huge interests that are very unlikely to be defeated...

As to public access and use, the picture is no better and aggravates the perception of conflict and managerial inefficiency. Some interviewees considered visitors' relation with PESET's administration nonexistent or disrespectful. There are no programs for environmental education or even for interpretation. Several trails are degraded, which led to closure of one of the accesses to Alto Mourão peak in the Itacoatiara area due to the extent of erosion. Such deficiencies were obvious signs of a lack of investment by IEF in public-use management of PESET, another visible side of the absence of State commitment to conservation of the area. To make matters worse, signs that inform the park limits carry clichés irrelevant to its purpose and the most eye-catching word is "Forbidden".

As we consider the two actor groups' views separately, we can notice that those related to the current or past administration of the Park have a more positive view than non-administrative actors do. This seems not surprising, but many former administrators were members of NGOs that demanded the Park and nowadays have a strong criticism over actual ones. Almost $30 \%$ of speeches fall into cluster 3 for the first group, while for the second group they represent about $20 \%$. Negative speeches dropped to $51 \%$ and rose to $66 \%$, respectively. There were more administrative actors' speeches that classified into cluster 2, which can be linked to the acknowledgement of administrative demands, a perception that rose to almost $36 \%$ for that group of actors. Still for that group, the negative representation that dropped the most was that of conflict $(20.5 \%)$ and the one that rose highest was that of managerial problems (31.7\%). That is an alert signal of the importance to focus on this symbolic sphere, since both the local community and visitors see PESET from a very negative perspective. In that case, the view of conflict rises to $36.9 \%$ and that of real-estate speculation, to $18.8 \%$.

\section{CONCLUSIONS}

PESET's institutionalization process relates to the lack of definition of its boundaries and to the historic land-tenure conflicts in the region. Real-estate speculation occupied the locus left vacant by the feeble implantation of the Park in the institutional and territorial spheres, but it was seen as a force that, "finding the right people in the right places" ended up catalyzing the pro-Park movement. In the symbolic sphere, the Park itself was tarnished by the management agency's administrative inefficiency, as well as for being a paper park and for staging conflicts related to real-estate speculation, land-tenure and political situation. $\mathrm{Ne}$ vertheless, it is a Park that has great value locally as a recreational area and as a register of the region's political and geographical history. However, in spite of its biological relevance, people do not identify that aspect. Thus, the social representations must be understood so that its positive aspects can be highlighted, contribute to its regional insertion and aid in the management of the Park.

\section{REFERENCES}

BARDIN, L. Análise de conteúdo. Lisboa: Edições 70, 229 p. 1977.

BAUER, M.W. ; GASKELL, G. Towards a paradigm for research on social representations. Journal for the Theory of Social Behavior, Oxford, 29(2):163-186. 1999.

CASTRO, P.; LIMA, M. L. Old and new ideas about the environment and science: an exploratory study. Environment and Behavior, Edmond, 33(3): 400-423. 2001.

GERHARDT, C. AND ALMEIDA, J. A dialética dos campos sociais na interpretação da problemática ambiental: uma análise crítica a partir de diferentes leituras sobre os problemas ambientais. Ambiente $e$ Sociedade, Campinas, 8(2):1-31. 2005.

ORMSBY, A.; KAPLIN, B.A. A framework for understanding community resident perceptions of Masoala 
National Park, Madagascar. Environmental Conservation, Moiry, v. 32(2):156-164. 2005.

PAASI, A. Bounded spaces in the mobile world: deconstructing "regional identity". Tijdschrift voor Economische en Sociale Geografie, Utrecht, 2:137148. 2002.

PELUSO, M.L. O potencial das representações sociais para a compreensão interdisciplinar da realidade: geografia e psicologia ambiental. Estudos de Psicologia, Natal, 8(2):321-327. 2003.

PIMENTEL, D. S.; MAGRO, T. C. Argumentos para a conservação do Parque Estadual da Serra da Tiririca (RJ) - Muito além de preservar o verde. In: Congresso Brasileiro de Unidades de Conservação, 6. 2009, Curitiba. Anais... Curitiba: Rede Nacional Pró Unidades de Conservação; Fundação O Boticário de Proteção a Natureza, CD-Rom. 2009.
ROPPER, M. A difícil arte do planejamento participativo: a implementação da APA Estadual da Chapada dos Guimarães como exemplo de institucionalização territorial. In: Congresso Brasileiro de Unidades de Conservação, 2., 2000, Campo Grande. Anais... Campo Grande: Rede Nacional Pró-Unidade de Conservação; Fundação O Boticário de Proteção à Natureza, 2:69-78. 2000.

TERBORGH, J. The fate of tropical forests: a matter of stewardship. Conservation Biology, Washington, 14(5):1358-1361. 2000.

Why tropical parks are failing and what can be done about it. In: Nunes M.L.; Takahashi, L.Y.; Theulen, V. (Org.). Unidades de conservação: atualidades e tendências 2007. Curitiba: Fundação O Boticário de Proteção a Natureza, pp. 296-297. 